\title{
Digital Agora: A Physical and Digital Space for Participatory Democracy
}

\author{
PEDRO HENRIQUE H.F. DE CRISTO \\ + D Studio
}

This paper presents the concept of the Digital Agora (DA): a physical + digital space for participatory democracy that responds to the global demand for more participation on the public decision making of cities by integrating specific public policies for instruments of direct democracy, spaces for systematization, synthesis and articulation, and effective technologies to generate a new calibration between representative and direct democracy at the city level.

\section{INTRODUCTION}

Democracy is the crowing institutional achievement in the history of the western world. Its challenge today: to adapt to a new scale of knowledge and participation demanded by citizens as a result of the accumulated technological and educational advancements to date in a world with unseen urban density. During the 5 th and 6 th centuries BC, the ascendance of political and spatial transformations resulted in the creation of Democracy. From the 14th century to now, men intensified mastering the knowledge to transform space and energy into technological instruments, resulting in the creation of a new form of space: the digital. Democracy now is in acute need of a new institutional design that integrates public policy, space and technology in pursuit of the ideal calibration of representative and direct democracy.

\section{AGORA, DEMOCRACY AND ATHENS}

Much like Mega Cities of today, Ancient Athens had an unprecedented scale and diversity, which challenged its society to lead itself in a new way [1]. The educational and technological leap produced by this civilization resulted in constant changes in the interactions between its citizens. At the forefront of Athens' growth, were new political powers that emerged outside of aristocratic circles, which until then had controlled all public decision making in the city-state. Along with the growth of the city, the reforms of Solon in 594 BC expanded political and economic rights to more citizens causing further disruption to existing power structures and creating opportunities for bolder change. Communication and engagement regarding knowledge about public decision making became gradually more difficult due to the size of the city and the pressures for power sharing grew progressively stronger. The disconnection between the aristocracy and the plebeians became increasingly unsustainable, resulting in an intense wave of protests and insurrections in the 6th century BC. The aristocratic practices proved obsolete in responding to this new reality. The empowered plebeians demanded structural changes, first and foremost more political participation. In 508/7 BC, acting both under pressure and progressively, Klisthenes, recently raised to power and aware of the demands of the population, delivered on his promises changing the history of humankind. Democracy was born, synthesis of a spatial and political reform. The most important reform was the organization of the city-state into areas called demes and the subsequent allocation of political power with deliberative capacity to the communities in these spaces. This created an integrated system of representative and direct democracy: This system was structured in three regions [trittyes], whose populations were divided into the demes, communities of 100-1,000 citizens. After mapping and defining the boundaries of the demes, they were organized into 10 groups of roughly 3,500 citizens each, called phyles. The phyles became the basis of composition for the new Council [boule], which grew in size from 400 to 500 members. Each phyle had fifty representatives selected annually through a random lottery, statistically the most representative method to this day. With this organization, all of the eligible citizens of Athens also became eligible to participate as part of the Magistrate [dikasteria], previously a privilege of the aristocracy. Jurors were selected through a random lottery out of the sample of citizens present at the tribunal each day. Simultaneously, the Assembly [ekklesia], open to any citizen in attendance, had its scope of deliberation increased. Political power transitioned from family affiliation to be shared and based on the spaces of origin of citizens. The city without police advanced its own self-governance through the decentralization of power in a calibration of representative and direct democracy. Each deme had the right of autonomy to decide on the majority of its daily matters, but had the duty to report on its performance to its own population and the central institutions of Athens. At the center of this system were formal and informal agoras that served as a public space and institution for the day-to-day decisions of the deme. These Agoras became the centers of life in the city-state. Near the Acropolis, the main Agora of Athens was the hub of integration of political, social, economical and cultural life, with a library, museum, 

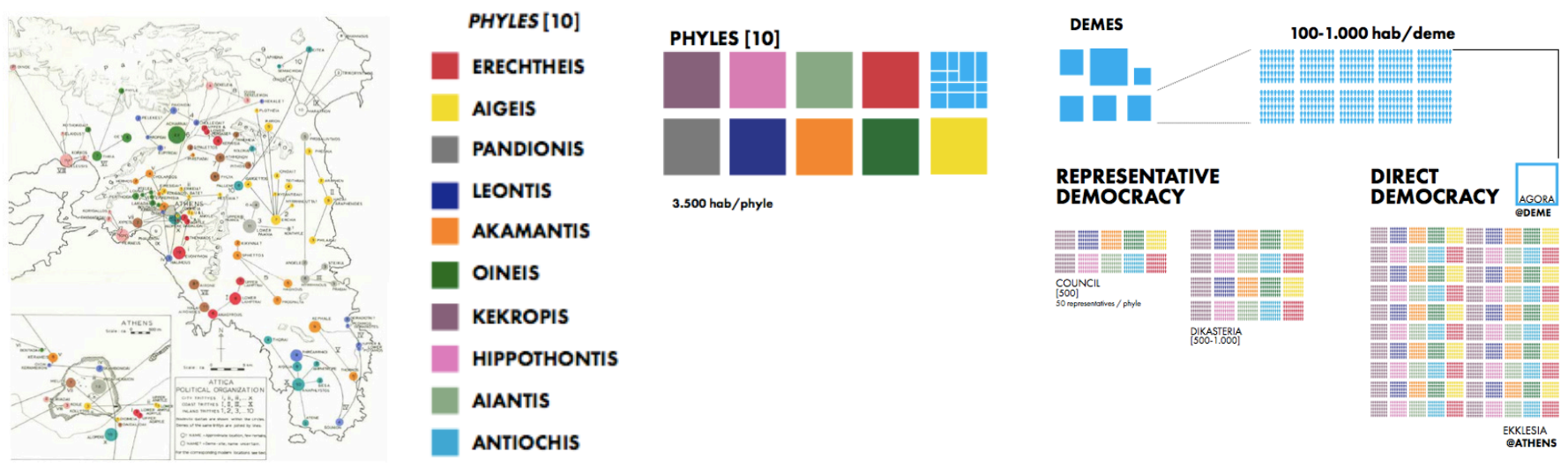

[Democracy in Athens] Figure 1: System of the phyles, demes, agoras and the three powers of Athenian Democracy

market and areas for sports and leisure. Near the main Agora, the pnyx, served the Assembly [ekklesia] as a space of debate and public decision- making. Every ten days, all of the citizens were invited to participate in a public meeting followed by a vote, thus characterizing direct democracy. Regular participation was around 5,000 out of a total of 40,000 citizens [12.5\%]. The innovation of Democracy in Athens made political power transition from families to spaces, becoming more decentralized and functioning in an institutional design that integrated direct and representative democracy. [2] In 461 $B C$, Pericles ascended to power installing an aristocratic autocracy. He represents the greatest paradox in the history of Ancient Greece. Capitalizing on the benefits of the democratic period, this politician was responsible for leading Athens Golden Age. However, due to his excessive concentration of power, Athens became disproportionately vulnerable to the mistakes of its leader, which ended up costing its independence in the Peloponnesian War (431-404 BC). Until its abrupt end, Athenian democracy was an innovative and productive cultural transformation that supported the development of the city-state. The following apogee and collapse at the hands of the same man serves as an undeniable proof of the limitations of individual judgement compared to the structured intelligence of society over the long term. Athens continued in a period of political instability under the command of foreign powers between 404 and 146 BC when the Roman Republic took control over all of Ancient Greece.

\section{SENATE, REPUBLIC AND ROME}

At the same time that Athens was living the emergence of democracy, Rome was beginning its own transformation. In 509 BC, evolving the sophisticated aristocratic culture of the Kingdom of Rome, the Roman Republic was instituted. Along with Athenian Democracy this model represents one of the two most important influences in our current system. The Republic was divided into three powers similar to the Athenian structure: 1) The Senate, 2) The Assembly, and the 3) The Magistrate, in practice subordinate to the Senate. Power in Rome continued to be primarily based on family affiliation, within the aristocracy. As such, Rome founded the first Republic: a system based on representative politics of the elites with a small degree of popular representation in the lower level of its Assembly. Similar in the structuring of their central institutions, Athenian Democracy and the
Roman Republic differed greatly in the imagination and use of their spaces. Athens decentralized political power not only by allowing any citizen to serve as a member of the Council, Assembly and Magistrate but also by delegating power to the phyles through the demes, each with its own agora. Conversely, Rome concentrated political power and public decision making in the heart of the republic, the Forum. In a time of constant war between states in which power over people proved to be more effective than power with people the Roman Republic outlasted Athenian Democracy. As a result of the developments in Rome and general instability in Athens in a great deal due to the rise and fall of Pericles, in $146 \mathrm{BC}$ Rome invaded and conquered all of Greece, dominating the society that had originally inspired it culturally. The Republic alternated between the control of the Senate and its dictators until in $45 \mathrm{BC}$, the Lex Titia granted unilateral power to a council of three, leading the Republic to its final end in 27 AD. The two main differences between the democratic system in Athens and the Republic in Rome were concentrated in: 1) The calibration of representative and direct democracy and; 2 ) The basis for determining the origin of political power of citizens: space $x$ aristocracy.

\section{MODERN DEMOCRACY AND CITIES}

After five centuries of political, spatial and technological innovation the civilizations of the western world entered into a period dominated by Empires, Kingdoms and Autocracies. From 27 AD until 1215 AD, when feudal barons unsatisfied with King John wrote the Magna Carta in England, men ruled like Gods. During these Dark Ages, rulers, with the support of the Church, limited the free exchange of knowledge that characterized Athenian Democracy and the Roman Republic while feudal public spaces became self-contained instead of connected to the world as in Athens or Rome. After the Renaissance, the swerves produced in the 19th and 20th centuries shifted the organization of the power of nations progressively from kingdoms, autocracies and dictatorships towards representative democracies, for what is now $48.5 \%$ of the world's population [EIU, 2015]. The model of representative democracy proved to be not only more precise in its principles, but also more effective in protecting the lives and interest of citizens. It is a fact that there has never been a famine crisis in a democratic country [Sen]. However, the possibilities of this system of government have demonstrated themselves to be insufficient for 

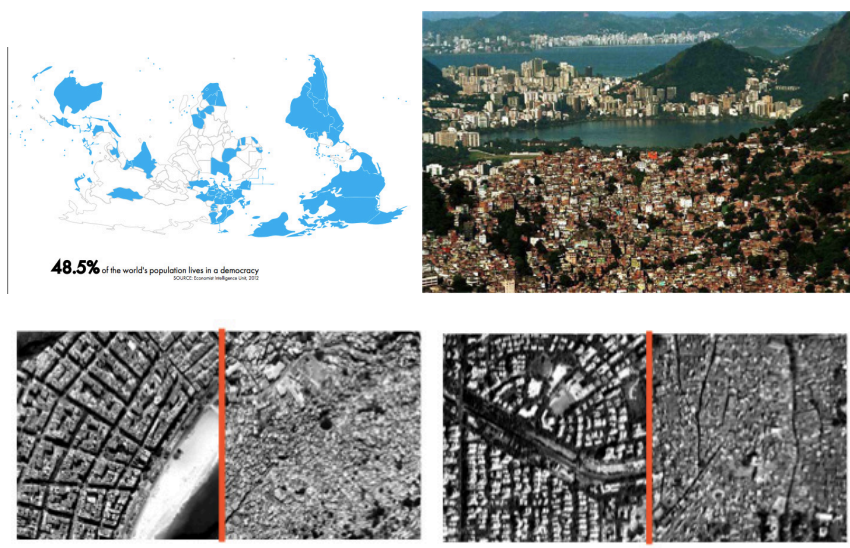

RIO DE JANEIRO
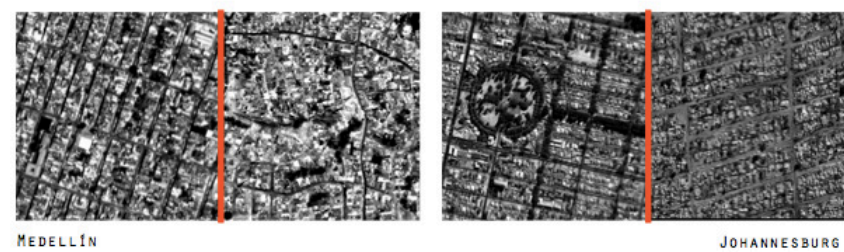

DIVIDED CITY@MAJORITY WORLD

[Democracy Globally and the Divided City Program] Figure 2: Map of democracies in the world and examples of divided cities.

today's demands. The evolution of the state, of politics and of democracy itself have not accompanied the evolution of cities, technology and consequently the new levels of access to knowledge and agency made possible by these. Today, the democratic system is in need of a new calibration that balances Direct and Representative Democracy in new forms of space, institutional design [public policy] and technology to make new scales of participation possible. It is highly probable that this innovation will only happen in a democratic system that integrates Physical + Digital Space.

IV. DEMOCRACY NOW IN CITIES: Cities represent the most intense concentrations of and interactions between people, capital (social, financial and human), knowledge, transformations of space and use and innovation of technology. The city is the scale most appropriate for the application of direct democracy because it is the scope of government most concrete and present in the interactions of citizens in their day-to-day lives and spaces. It is within the city that citizens are capable of most directly experimenting with the effects of their deliberations, whether individually or collectively and learn from them. For the first time in history [2009], more than half of the world's population lives in cities. A process of urban migration without precedent is taking place during the 21st century: by 2050 , the urban population of developed countries will grow by only 200 million by 2050, while that of the Majority World [developing countries] will grow by 2.7 billion [UN, 2014]. Most of the urban growth will take place in Africa and Asia. Latin America, already urbanized, constitutes a living laboratory for the cities of the Majority World. The main challenge of this staggering growth is to anticipate, integrate and develop the Divided City, especially its most underprivileged areas: the slums. The social, economic and political inequalities in the cities of the Majority World have resulted in this spatial program, not often declared but mercilessly executed by the holders of political power. Cities work as a system, and systems even though usually designed from the top down are decided in their effectiveness from the bottom up. Slums are the part of urban areas that are growing the most [Werthmann, 2011]. In 2050, informal settlements will account for nearly half of the world's urban population and $1 / 3$ of its total, making it increasingly necessary that urban integration and political evolution go hand in hand. As reference for Asia and Africa in the process of urbanization, Latin America [75\% urbanized] constitutes the most important laboratory for public policy and urbanization in the Majority World today. For the most part, the scope of challenges that will be faced by Africans and Asians is being confronted there. From the existing democratic processes or lack of them to services, mobility/connectivity, sanitation and title rights, resilience against crises of violence and climate change; these are the efforts necessary for the poorest areas to be developed and urban migrants to be integrated.

\section{DIVIDED CITY CHALLENGES@DEMOCRACIES}

Assessing the current state of our democracies some clear challenges arise in a similar way even In different contexts such as Brasil, South Africa, India, China, Europe or the US itself. In this sense, there are presented bellow the main systemic problems identified during research about the core program of representative democracy, they are:

1. Asymmetry of knowledge, agency and engagement in public decision making;

2. Disconnection between digital activism and physical spaces for the realization of democracy;

3. Lack of opportunities to participate in public decision making;

4. Public performance and direct democracy in institutional design;

\section{Failure to realize the Right to the City;}

"The right to the city is far more than the individual liberty to access urban resources: it is a right to change ourselves by changing the city. It is, moreover, a common rather than an individual right since this transformation inevitably depends upon the exercise of a collective power to reshape the processes of urbanization. The freedom to make and remake our cities and ourselves is, I want to argue, one of the most precious yet most neglected of our human rights." -David Harvey In Places in the Making: How Placemaking Builds Places and Communities, MIT + DUSP MIT, p. 6

VI. DIGITAL AGORA PROGRAM: As a response to these problems the author and collaborator propose the creation of a new public program primarily dedicated to the practice of direct democracy in substitution to the city legislative but also fit to serve schools on coding and robotics literacy and communities by hosting a public database and a mapping center. To create this program the following design matrix and process have been essential; DESIGN MATRIX: In our existence, people matter the most. We live in space, and through the exchange 


\section{$R \& D^{2}$ PROCESS}

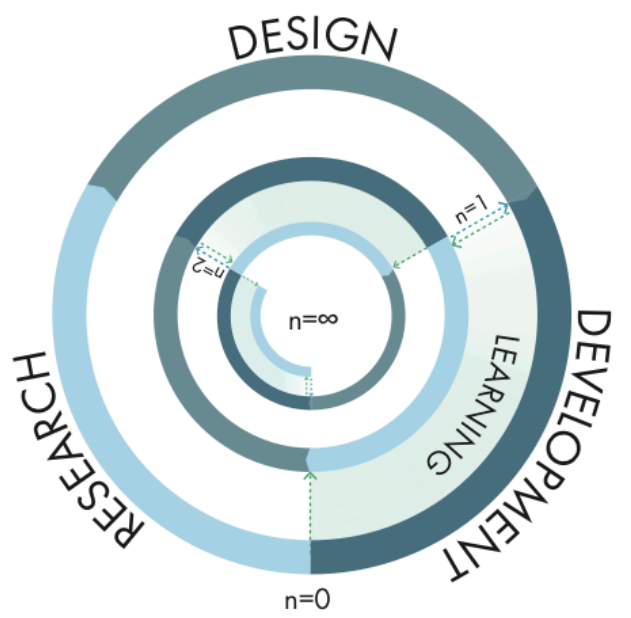

[3 R\&D² Process] Figure 3: Research, Design and Development Process for architecture, urbanism, city design, policy and technological innovation.

shall have its most important application. Initially developed mainly in the scale of industrial design, and firstly articulated at here, specially for architecture, urbanism and landscape design, $R \& D^{2}$ is the most effective way for cities to know, plan and develop in an anticipatory manner, serving their citizens while providing social justice and quality of life in a progressive way. Most importantly, with the Digital Agora as the core instrument for its application, this process must serve and empower citizens to engage with more knowledge, agency and creative capabilities on the transformation of their own cities. Applied in this process are the following elements for synthesis; Space: the spatial program of the project is focused in the integration of physical and digital space while at the same time it works as a multi-functional equipment under shared leadership between government and the community. As this space might serve as a public policy intervention, it is designed to be scalable and adaptable to different levels of resources, topographies, and social contexts; Public Policy: the principal public policies of the Digital Agora are concentrated in the integration of the development of knowledge, agency and deliberation on the part of citizens in respect to the democratic process and the city, and; Technology: Understanding the equipment as a hub and unified database operating between physical and digital space, it can make use of mobile phones, computers and a sensor network within its community as communications infrastructure for the collection and dissemination of data, information and knowledge. This in turn functions as an area of extension and concentrated digital activity for the community in relation to the space and city within which it lies. In practice the Digital Agora System is designed to work as follows: EDUCATION, AGENCY AND DELIBERATION: The Digital Agora is a public equipment that is directly connected to schools. In the flow of human capital, it serves as a hub and complementary space for activities that develop the knowledge and agency of students in the democratic process, public good and the city. For adults, the Agora serves to educate, strengthen agency and create opportunities for deliberation in the self-governance of the community and the city.
It works in a cycle for adults and children to participate, and in turn . educate and involve their peers to sustain the effect of engagement. In partnership with schools, the Digital Agora prepares new generations with more knowledge and agency regarding the public good, resulting in adult citizens who are better prepared for and more active in the exercise of deliberation. This deepens the effect of citizenship and produces progressively better results in community self-governance and participation; DEMOCRACY, DATA AND TECHNOLOGY: Democracy allows for a larger exchange of ideas and consequently development of knowledge in comparison to autocratic regimes, thus fostering a greater pace of technological innovation. The Digital Agora functions as a hub for the collection and dissemination of data, information and knowledge using the network of mobile phones, computers and sensors in the community as communications, articulation and research infrastructure. It serves the community by being the hub for the unified database of residents while also filtering and organizing official data from the Center of Operations of the City Hall and research institutions. This unified database serves the activities of deliberation and research using the mobile, computing and sensor community infrastructure in the establishment of an open database. In Rio, and anywhere with internet, those interested can process data and produce knowledge in a collaborative, continuous and evolutionary way; PARTICIPATORY BUDGETING AND DIRECT DEMOCRACY@ CITY LEVEL: The mission of the Digital Agora system is to provide education, facilitate public advocacy and empower agency, but it is essentially a system for deliberation, and deliberation naturally involves the decisions regarding resources for the community, city and the possible interventions they could be directed towards. The Digital Agora works based on the scope of public deliberation of citizens in their spaces of origin (ex: the community of Vidigal votes to determine the areas of intervention and direct the investments that occur in Vidigal). Instruments such as Participatory Budgeting are essential in this process of developing direct democracy. The Digital Agora reform initiates with participatory budgeting, to then move gradually to the establishment of direct democracy in the city assembly [chamber of representatives]. SCALES OF THE SYSTEM: The scales of implementation of the Digital Agora system are [1] The equipment and its surroundings; [2] The community in which it is located [1 DA per 25,000 inhabitants or $x$, according to measured efficiency]; [3] Its area of integration [between 2-5] communities + neighborhoods and the City Network of D.As. SPATIAL/FUNCTIONAL PROGRAM: The spatial program of the Digital Agora is divided into three main areas: [1] Systematization: composed of spaces for reading, learning and research; [2] Synthesis: with spaces for design, visual, artistic and functional production and integration of different production activities; [3] Articulation: space dedicated to social activities, culture, mobilization, public advocacy and deliberation in processes of direct democracy. SCALES OF THE EQUIPMENT: The Digital Agora will be developed as a public equipment in three scales: [100] Temporary [200] Permanent [300] Permanent/Large [+]; each designed with different versions of the same spatial program based on Systematization, Synthesis and Articulation. 


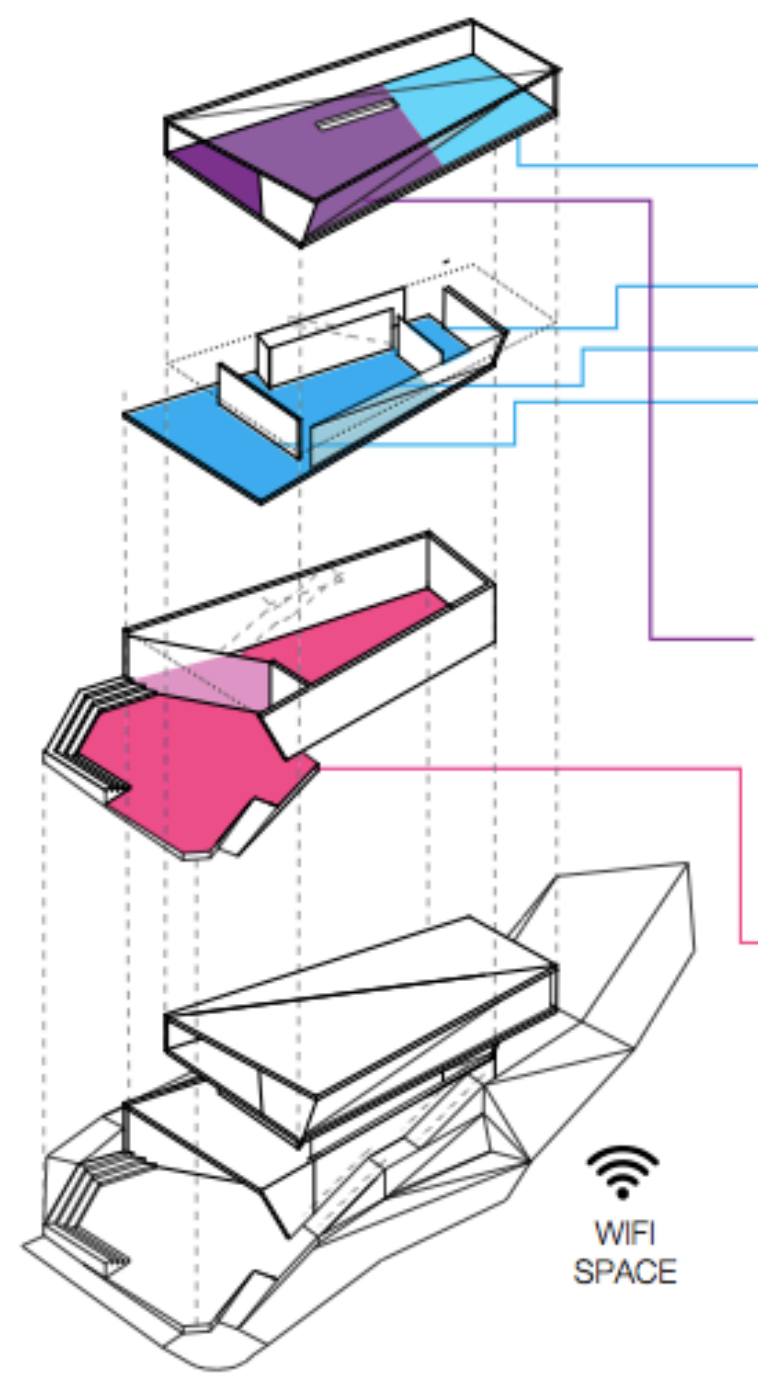

\section{SYSTEMATIZATION}

- $75 \mathrm{~m}^{2}$ Tा CLASSROOMS

$50 \mathrm{~m}^{2}$ CODING CLASSROOMS

- $35 \mathrm{~m}^{2}$ REFERENCE ROOM R

-135 $\mathrm{m}^{2}$ TाT LIBRARY

- $70 \mathrm{~m}^{2}$ oBSERVATION AREA

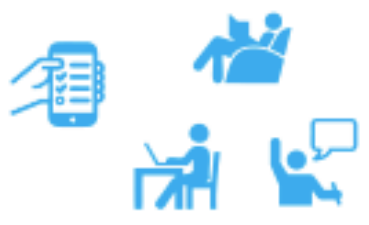

-SYNTHESIS

$150 \mathrm{~m}^{2}$ FABLAB / STUDIO

MEDIA SPACE: PRODUCTION

THACKER SPACE

細

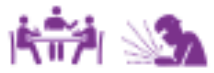

- ARTICULATION

$240 \mathrm{~m}^{2}$ a EXHIBITON SPACE

IT MEDIA SPACE: COMMUNICATION

阐

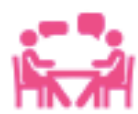

\section{- AGORA}

$22 \mathrm{~cm} 2$ if PUBLIC SPACE

\section{AREA OF INTEGRATION}

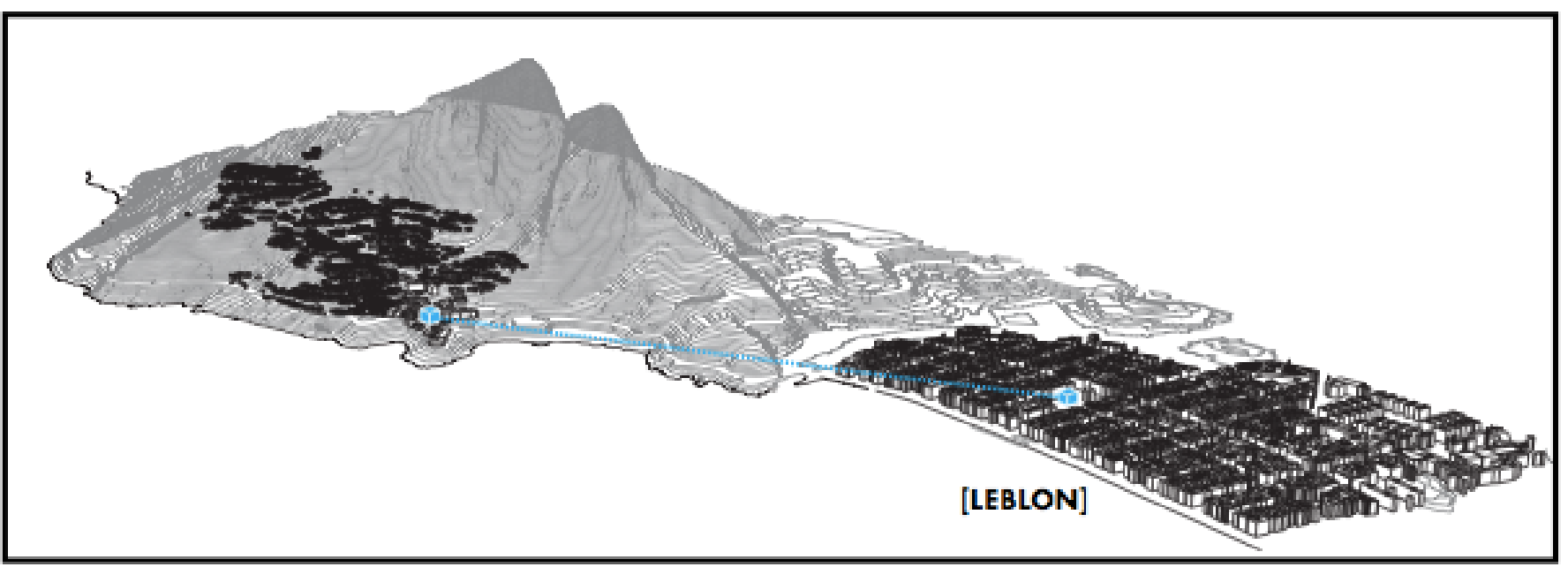

[4] Digital Agora Program and Strategy: Systematization, Synthesis and 


\section{CONCLUSION}

The Digital Agora has been conceptualized to extend from the city of Rio de Janeiro to propose a Democratic Reform for cities in Brazil and other democracies based on the understanding that there must be a collective effort to find the precise calibration for the application of direct democracy at the city level. It serves a larger discussion and movement for the realization of the demands for more participation in public decision-making present in recent protests around the world and demonstrates how space, policy and technology need to be synthesized for citizens to realize their right to the city, data and democracy itself. It integrates the knowledge of different disciplines through design to propose both a new system and program for the advancement of democracy and the creation of more progressive cities.

\section{ENDNOTES}

1. Agathe Institute. Democracy. Accessed on 31 January 2014. http://www.agathe. gr/democracy/ Ammerman, Albert J. "On the Origins of the Forum Romanum." American Journal of Archaeology. 94:4 (Oct, 1990) pp. 627-645. JSTOR Stable Link: < http://www.jstor.org/stable/50512>.

2. Crawford, Susan. "New Case Study: The Mayor's Office of New Urban Mechanics and the Evolution of CRM in Boston." 7 August 2013. Accessed on 31 January 2014. <scrawford.net/new-case-study-the-mayors-office-of- new-urban-mechanicsand-the-evolution-of-crm-in-boston/>.

3. Fung, Archon, Jane Mansbridge, and Dennis F. Thompson. "A Systemic Approach to Deliberative Democracy." Deliberative Systems: Deliberative Democracy at the Large Scale. Ed. Parkinson, John, and Jane Mansbridge. Cambridge University Press, 2012.

4. Ito, Mizuko, Kris Gutiérrez, Sonia Livingstone, Bill Penuel, Jean Rhodes, Katie Salen, Juliet Schor, Julian Sefton- Green, S. Craig Watkins. 2013. Connected Learning: An Agenda for Research and Design. Irvine, CA: Digital Media and Learning Research Hub.

5. Isham, Jonathan, Deepa Narayan and Lant Pritchett. "Does Participation Improve Performance? Establishing Causality with Subjective Data." World Bank Economic Review, 9:2 (1995) pp. 175-200..

6. Osbore, Robin. "Did Democracy Transform Athenian Space?" British School at Athens Studies, 15, Building Communities: House, Settlement and Society in theAegean and Beyond (2007). pp. 195-199. Accessed on 31 January 2014. JSTOR

6. Sen, Amartya. Development as Freedom. New York, NY: First Anchor Books, 1999. Sen, Amartya. The Idea of Justice. London: Penguin Books, 2009.

7. Thompson, Homer A. "The Agora at Athens and the Greek Market Place," The Journal of the Society of Architectural Historians, 13: 4 (Dec, 1954). pp. 9-14. Accessed on 31 January 2014. JSTOR stable link: <http://www. jstor.org/ stable/987633> 